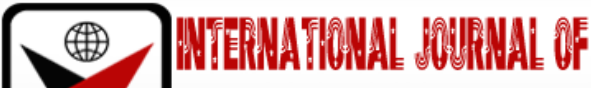

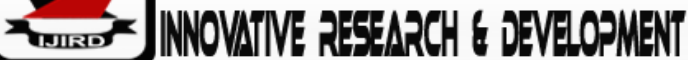

ISSN 2278-0211 (Online)

\section{Analysis of the Effect of Rock Properties on Extraction-Haulage System Performance}

\author{
Patrick Adeniyi Adesida \\ Lecturer, Department of Mining Engineering, \\ Federal University of Technology, Akure, Nigeria
}

\begin{abstract}
:
This paper investigates the effect of rock properties on loading-hauling system performance. Sample of fragmented rocks from two different quarries (JCC and Dortmund) were collected and tested in the laboratory to obtain their average density. Results of the Schmidt hammer test carried out and that of rock density were used to estimate the compressive strength of the rock samples. The loading and hauling operations were monitored to compute the truck cycle time and bucket filling rate of the two quarries. The results obtained showed that average rock density at JCC and Dortmund quarries are $2.57 \mathrm{~g} / \mathrm{cm}^{3}$ and $2.68 \mathrm{~g} / \mathrm{cm}^{3}$ respectively. The uniaxial compressive strength of JCC is $115.90 \mathrm{MPa}$ while that of Dortmund is 185.00 MPa. Analysis between rock properties and performance characteristics at the two quarries was carried out. The result shows that the truck cycle time at JCC quarry ranges between 25.00 25.70 min while the bucket filling rate varies between 0.0384- 0.0460 min. Similarly for Dortmund quarry, the cycle time varies between $13.27-13.88$ min while the bucket filling rate ranges between $0.0380-0.0420 \mathrm{~m}^{3} / \mathrm{s}$. The Dortmund quarry has the lowest cycle time and bucket filling rate of 13.27 min and $0.0380 \mathrm{~m}^{3} / \mathrm{s}$ respectively. Therefore, rock properties vary inversely as the equipment performances (the higher the rock density and uniaxial compressive strength, the lower the excavator bucket filling rate, truck cycle time and vice visa). Therefore, it can be concluded that strength parameters of rock play very important role in the loading-hauling system of quarries.
\end{abstract}

Keywords: Bucket filling rate, density, rebound hardness number, UCS, truck cycle time

\section{Introduction}

The ultimate goal of a mining operation is to provide a raw material to end users at the least expense with no or minimal damage to the environment. Key to this is the efficient utilization and accurate estimation of the extractionloading system. In open pit mines such as aggregates quarries, materials handling typically involves loading and transportation of fragmented rock from the mine or quarry face to dump sites using equipment such as shovels, trucks, rails, and conveyor belts. The productivity and efficiency of loading-hauling system is affected by several factors such as location design, truck-excavator matching and type of materials to be loaded (Manyele, 2017). It is therefore imperative that proper evaluation of the factors affecting mine transport machinery is done in order to bring about an optimum results and profitability in aggregates production.

Researchers have done series of work to investigate different factors that contribute to loading and haulage performance in open pit mines. Their studies have also suggested how to improve performance of loading and haulage system in mining operations (Adams and Bansah, 2016; Olaleye and Adagbonyin, 2011; Manyele, 2017;Singh and Narendrula, 2006).The efficiency of loading-hauling system in open-pit mines is also being reduced by factors like cycle time, traction, resistance, grade resistance, depth of mine face, altitude and gradient of haulage roads.

Moreover, cycle time which is the time required for an equipment to make one complete cycle of operation is often use to evaluate equipment performance and operators' efficiency (Nwanyaet al., 2017). Also, the rockstrength parameters have noticeable bearing on excavation loading operation in quarries (Adebayo and Aladajere 2013). Thus, the knowledge of the impact of rock strength parameters on excavation, mucking and loading operations, can be used to design a system that will improve the cycle time and efficiency of equipment in mining operations.However, information about the effect of rock's properties on loading-hauling system performance especially in the quarry face are almost not available. Therefore, this paper will focus on factors affecting the performance of loading and haulage equipment such as cycle speed and bucket filling rate; and evaluates the effect of rock properties with performance characteristics at the study areas.

\section{Materials and Methods}

Two quarries (JCCand Dortmund) which are both located in Akure North Local Government Area of Ondo State in the western part of Nigeria which is located between the longitude of $7^{\circ} 16^{\prime} 0^{\prime} \mathrm{N}$ to $7^{\circ} 17^{\prime} 0^{\prime} \mathrm{N}$ and latitude of $5^{\circ} 14^{\prime} 30^{\prime} \mathrm{E}$ to $5^{\circ} 15^{\prime} 30^{\prime} \mathrm{E}$ were selected for the study. The location is part of the Precambrian basement complex of the southwestern Nigeria. Materials used for this work consisted of rock samples collected at the mine face of the quarries under 
consideration. The samples were obtained from the fragmented rock obtained following blasting operation. Five different samples were collected from each face of the quarries.

\subsection{Determination of Rock Density and Uniaxial Compressive Strength}

Using the standard procedures suggested by (ISRM, 1995), the density of the rock samples collected were measured. Equation (1) was used to obtain the bulk density.

$$
\text { Bulk Density }(\rho)=\frac{M}{\Delta V}\left(\mathrm{~g} / \mathrm{cm}^{2}\right)
$$

where $M$ is the bulk sample mass and $\Delta V$ is change in volume and it is presented in Equation 2.

$$
\Delta V=\text { bulk volume }\left(V_{f}-V_{i}\right)(2)
$$

where $V_{f}$ and $V_{i}$ are the final and initial cylinder readingrespectively.

Through the Schmidt hammer rebound hardness test an indirect method of determining the Uniaxial Compressive Strength was adopted in this study. The standard procedures for the Schmidt Hammer test which conform to ISRM (1981) and ASTM (1994) method was followed. For the purpose of this project, twelve (12) rebound tests were undertaken at five different points on the outcrop (totalling sixty (60) data) from each quarry face. Corresponding Uniaxial Compressive Strength (UCS) values were obtained from the Deere and Millers correlation chart for Schmidt (L) hammer, relating rock density, compressive strength and rebound number shown in Figure 2.

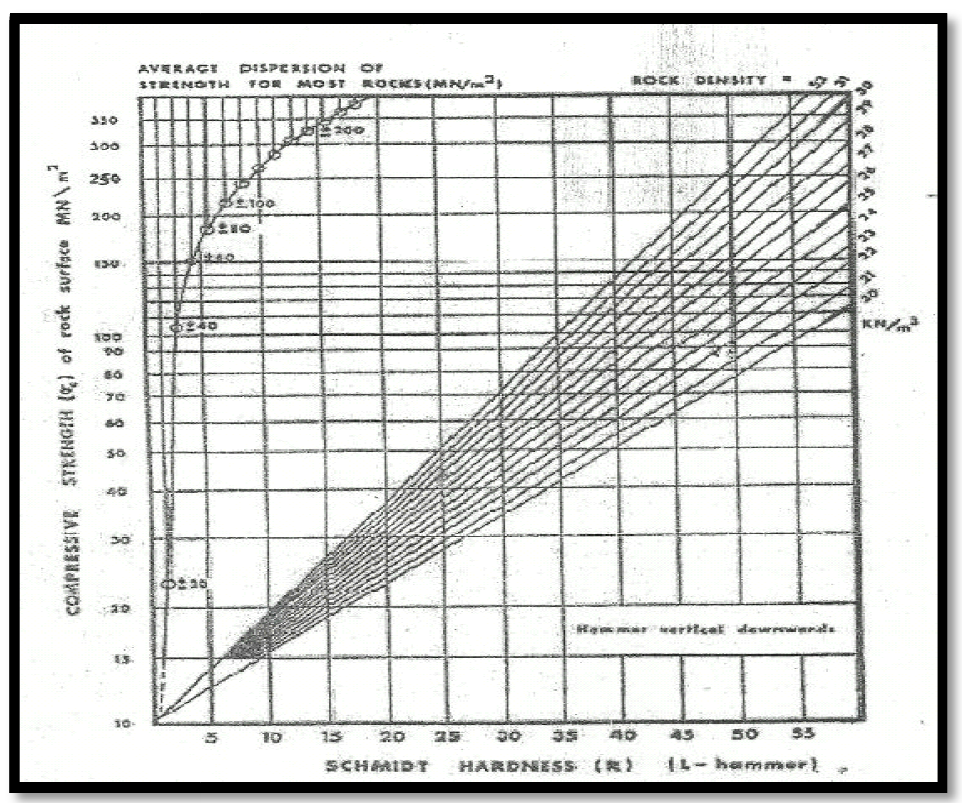

Figure 1: Correlation Chart for Schmidt Hammer, Relating Rock Density, Compressive Strength and Rebound Number (After Deere and Miller, 1966)

\subsection{Haul Truck Cycle Time}

The truck cycle time is measured from the time the truck is filled at the loader, travels full to the dumpsite, dumps the load, and travels empty to the loader to join a queue and positions itself for the next load (spotting). The truck cycle time comprises load time, the travel and return time, dumping time, queuing time (and other delays) and spotting time. For the purpose of this project work, the following denotations and equations will be used;

$$
\mathrm{t}_{1}=\frac{\mathrm{Gt}_{\mathrm{ex}}}{60 \mathrm{~V}_{\mathrm{b}} \mathrm{K}_{\mathrm{f}} \mathrm{Y}}
$$

Wheret $t_{1}$ is loading time of dump truck ( $\mathrm{min}$ ), $\mathrm{G}$ is the capacity of dump truck (ton), $\mathrm{t}_{\mathrm{ex}}$ is the cycle time of excavator (sec), $V_{B}$ is the volume of excavator bucket $\left(\mathrm{m}^{3}\right)$, Kfis fill factor of excavator bucket, $\mathrm{Y}$ is the density of fragmented material (ton $/ \mathrm{m}^{3}$ ). The travel and return time for truck is denote with $\mathrm{t}_{2}$ and it is defined using equation 4 to 6 .

$$
\begin{aligned}
& \mathrm{t}_{\text {travel }}=\frac{60 L R}{V_{L}} \\
& \mathrm{t}_{\text {return }}=\frac{60 L R}{V_{\text {em }}}(5) \\
& \mathrm{t}_{2}=\mathrm{t}_{\text {travel }}+\mathrm{t}_{\text {return }}=\left(\frac{60}{\mathrm{~V}_{\mathrm{L}}}+\frac{60}{\mathrm{~V}_{\mathrm{em}}}\right) \mathrm{L}
\end{aligned}
$$

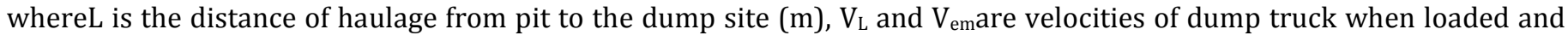
when empty respectively ( $\mathrm{m} / \mathrm{sec}), \mathrm{R}$ is the factor for acceleration and retardation of dump truck (1.25).

The travel and return time of the haul truck depends on the grade of the vehicle's weight and power, the condition of the haul road, the grades encountered and the altitude above sea level. All these will not be considered in the course of this project. Thus, the haul-truck cycle time can be expressed using Equation (7).

$$
T_{c y}=t_{1}+t_{2}+t_{3}+t_{4}+t_{5}
$$

where $_{3}$ is offloading time ( $\left.\mathrm{min}\right), \mathrm{t}_{4}$ is idle time ( $\left.\mathrm{min}\right) \mathrm{andt}_{5}$ is spotting time for loading and offloading (min). 


\subsection{Backhoe Excavator Bucket Filling Rate}

Excavator bucket filling rate is defined as the ratio of the volume in cubic metres of the excavator bucket to its scooping time in seconds. The capacity of the bucket, mechanical properties of the rock in question which may include its rock density, its uniaxial compressive strength and its point load index to mention few and lastly the efficiency of the operator are the major determinants of the bucket filling rate, but for the purpose of this project the efficiency of the operators are taken to be the same and are therefore negligible in course of value computation. Equation (8) is applied to estimate the excavator filling rate.

$$
E B_{v}=\frac{B_{c}}{T_{s p}}
$$

Where $\mathrm{EB}_{\mathrm{v}}$ is the excavator bucket filling rate $\left(\mathrm{m}^{3} / \mathrm{s}\right), \mathrm{B}_{\mathrm{c}}$ is the bucket capacity $\left(\mathrm{m}^{3}\right)$, that is, the total volume of fragmented rock materials that will completely fill the bucket of an excavator and $\mathrm{T}_{\mathrm{s}}$ is the scooping time ( $\mathrm{s}$ ) which is the time taken to completely fill the bucket of an excavator with the fragmented rock materials.

\section{Results and Discussion}

The uniaxial compressive strength, rebound hardness vale and the density of rock samples from the selected quarries were evaluated and the result is shown in Table 1. The result shows that the rock being evaluated falls within the range of hard rock in according to the classification of Mohamed et al (2015). This is also supported by results from other researchers when relatively comparing UCS and rebound hardness values (Aydan et al., 2014; Heather et al., 2011; Wang et al., 2016).

\begin{tabular}{|c|c|c|c|c|c|c|}
\hline Quarry & \multicolumn{3}{|c|}{ JCC } & \multicolumn{3}{c|}{ Dortmund } \\
\hline Point & $\begin{array}{c}\text { Rebound } \\
\text { hardness }\end{array}$ & $\begin{array}{c}\text { Density } \\
\left(\mathrm{g} / \mathrm{cm}^{3}\right)\end{array}$ & $\begin{array}{c}\text { UCS } \\
(\mathrm{MPa})\end{array}$ & $\begin{array}{c}\text { Rebound } \\
\text { hardness }\end{array}$ & $\begin{array}{c}\text { Density } \\
\left(\mathrm{g} / \mathrm{cm}^{3}\right)\end{array}$ & $\begin{array}{c}\text { UCS } \\
(\mathrm{MPa})\end{array}$ \\
\hline 1 & 48.50 & 2.50 & 115.00 & 52.48 & 2.55 & 125.1 \\
\hline 2 & 49.70 & 2.40 & 113.00 & 53.60 & 2.80 & 219.7 \\
\hline 3 & 46.90 & 2.63 & 116.50 & 52.17 & 2.74 & 195.2 \\
\hline 4 & 47.48 & 2.60 & 117.00 & 54.50 & 2.80 & 229.8 \\
\hline 5 & 46.00 & 2.73 & 118.00 & 51.30 & 2.48 & 134.2 \\
\hline
\end{tabular}

Table 1: Physical Properties of Rock Samples

\subsection{Haul Truck Cycle Time}

Truck cycle time for each quarry were calculated and results are presented in Tables 2 and 3. The results showed truck cycle time varied from 25.00-27.21 min for JCC quarry, whilst that of Dortmund quarry varied from 13.27-13.88 min. It could be inferred that JCC quarry has higher truck cycle time than that of Dortmund quarry. Factors responsible for these variations include the expertise of the operators, the distance of the quarry to the dump site, elevation and smoothness level of the haulage ways.

\begin{tabular}{|c|c|c|c|c|c|c|}
\hline Trip & $\begin{array}{c}\text { Loading Time } \\
\text { (min) }\end{array}$ & $\begin{array}{c}\text { Travel and } \\
\text { Return Time } \\
\text { (min) }\end{array}$ & $\begin{array}{c}\text { Dumping } \\
\text { Time (min) }\end{array}$ & $\begin{array}{c}\text { Waiting } \\
\text { Time } \\
\text { (min) }\end{array}$ & $\begin{array}{c}\text { Spotting } \\
\text { Time (min) }\end{array}$ & $\begin{array}{c}\text { Truck Cycle } \\
\text { Time (min) }\end{array}$ \\
\hline 1 & 8.43 & 5.50 & 0.98 & 10.74 & 0.83 & 26.48 \\
\hline 2 & 8.58 & 5.20 & 0.92 & 11.63 & 0.88 & 27.21 \\
\hline 3 & 8.13 & 5.20 & 0.90 & 10.48 & 0.87 & 25.58 \\
\hline 4 & 8.25 & 5.25 & 1.00 & 10.38 & 0.82 & 25.70 \\
5 & 8.04 & 5.46 & 0.87 & 9.70 & 0.93 & 25.00 \\
\hline
\end{tabular}

Table 2: Tuck Cycle Time at JCC Quarry

\begin{tabular}{|c|c|c|c|c|c|c|}
\hline Trip & $\begin{array}{c}\text { Loading } \\
\text { Time (min) }\end{array}$ & $\begin{array}{c}\text { Travel and } \\
\text { Return Time } \\
\text { (min) }\end{array}$ & $\begin{array}{c}\text { Dumping } \\
\text { Time (min) }\end{array}$ & $\begin{array}{c}\text { Waiting } \\
\text { Time } \\
\text { (min) }\end{array}$ & $\begin{array}{c}\text { Spotting } \\
\text { Time (min) }\end{array}$ & $\begin{array}{c}\text { Truck Cycle } \\
\text { Time (min) }\end{array}$ \\
\hline 1 & 6.89 & 2.84 & 0.88 & 2.28 & 0.85 & 13.74 \\
2 & 6.75 & 2.76 & 0.92 & 2.00 & 0.86 & 13.29 \\
\hline 3 & 6.47 & 2.80 & 1.00 & 2.25 & 0.92 & 13.44 \\
\hline 4 & 6.83 & 2.50 & 0.96 & 2.20 & 0.78 & 13.27 \\
\hline 5 & 6.81 & 2.88 & 0.92 & 2.30 & 0.97 & 13.88 \\
\hline
\end{tabular}

Table 3: Truck Cycle Time at Dortmund Quarry

\subsection{Bucket Filling Rate}

Tables 4 and 5 present the results of bucket filling rate at JCC and Dortmund quarry respectively. The bucket filling rate varied from $0.0384-0.0460 \mathrm{~m}^{3} / \mathrm{s}$ atJCC quarry while atDortmund quarry, it varied from $0.019-0.045 \mathrm{~m}^{3} / \mathrm{s}$. This means that the bucket filling rate at JCC quarryfalls in higher range than that of Dortmund quarry. Operator's expertise is one major reasons for variations in bucket filling rate. As much as the level of expertise can be known, it is difficult to measure. Others may include the age and maintenance level of the equipment as well as the size of fragmented rocks to be 
hauled. Furthermore, Figures 2 and 3 presents the relationship between bucket filling rates and truck cycle time for the selected locations. The coefficient of determination for the relationships shows that the bucket filling rates for the two sites have a great and similar influence of the truck cycle time for the selected faces.

\begin{tabular}{|c|c|c|c|}
\hline Excavating Point & Scooping Time (s) & Bucket Capacity $\left(\mathrm{m}^{3}\right)$ & $\begin{array}{c}\text { Bucket Filling } \\
\text { Rate }\left(\mathrm{m}^{3} / \mathrm{s}\right)\end{array}$ \\
\hline 1 & 26.8 & 1.1 & 0.0405 \\
\hline 2 & 23.9 & 1.1 & 0.0460 \\
\hline 3 & 28.0 & 1.1 & 0.0393 \\
\hline 4 & 27.8 & 1.1 & 0.0395 \\
\hline 5 & 28.6 & 1.1 & 0.0384 \\
\hline
\end{tabular}

Table 4: Bucket Filling Rate for JCC Quarry

\begin{tabular}{|c|c|c|c|}
\hline Excavating Point & Scooping Time (s) & Bucket Capacity $\left(\mathrm{m}^{3}\right)$ & $\begin{array}{c}\text { Bucket Filling } \\
\text { Rate }\left(\mathrm{m}^{3} / \mathrm{s}\right)\end{array}$ \\
\hline 1 & 24.4 & 1.1 & 0.045 \\
\hline 2 & 55.0 & 1.1 & 0.020 \\
3 & 45.8 & 1.1 & 0.024 \\
4 & 57.9 & 1.1 & 0.019 \\
\hline 5 & 26.2 & 1.1 & 0.042 \\
\hline
\end{tabular}

Table 5: Bucket Filling Rate Dortmund Quarry

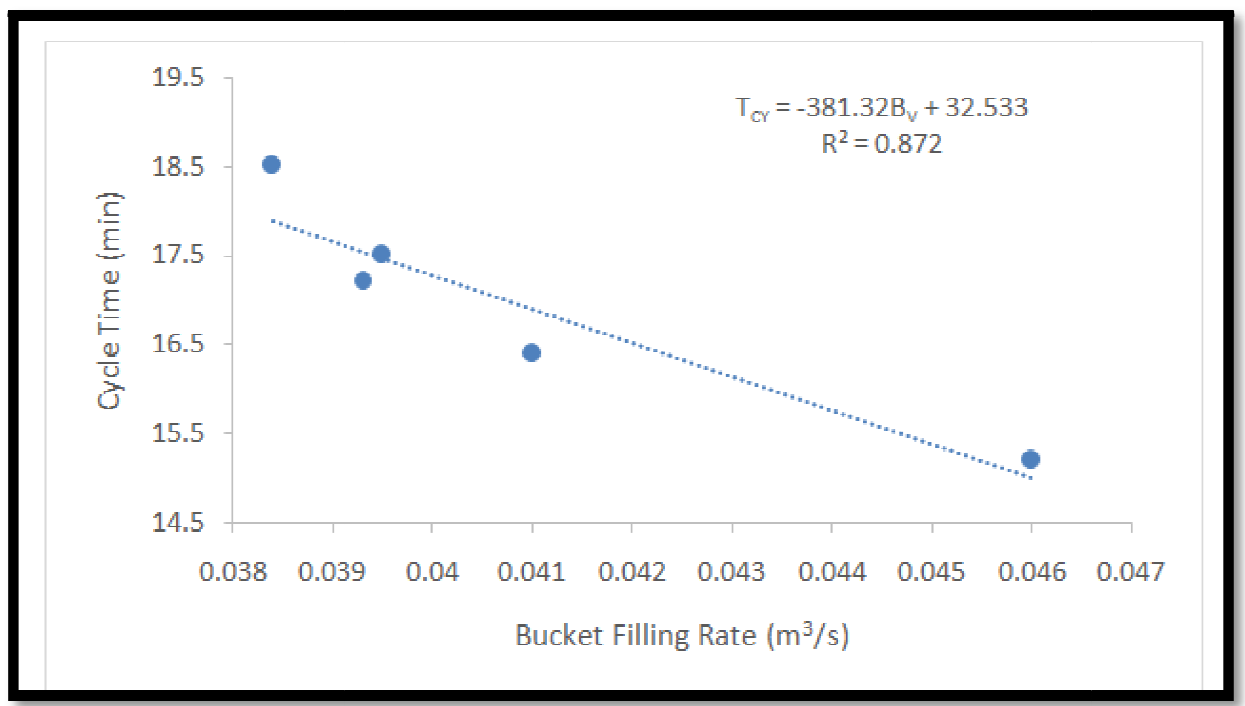

Figure 2: Truck Cycle Time against Bucket Filling Rate in JCC

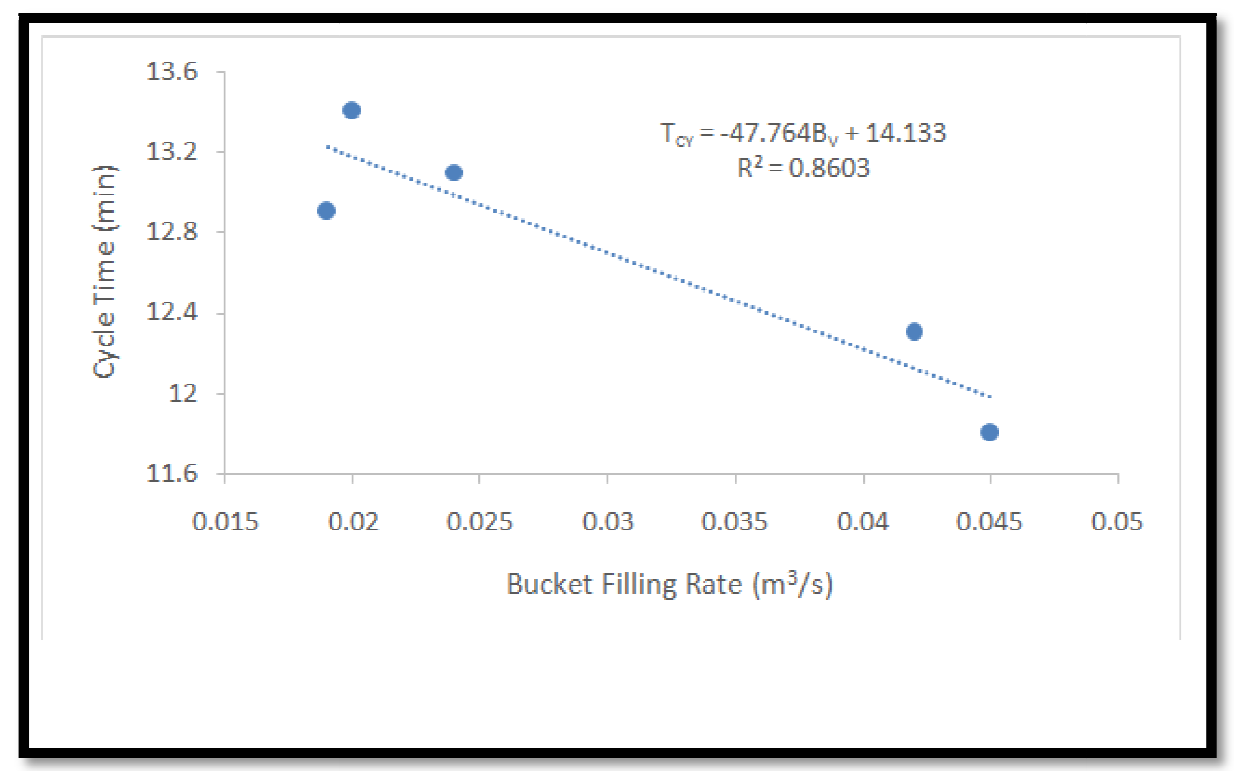

Figure 3: Truck Cycle Time against Bucket Filling Rate in Dortmund 


\subsection{Comparison between Rock Properties and Excavator Bucket Filling Rate}

Figures 4-6 presents the relationship between bucket filling rates and uniaxial compressive strengths, rebound hardness number and density for rock samples in the selected scooping points respectively. The analysis through the coefficient of determination $\left(\mathrm{R}^{2}\right)$ of the shows that uniaxial compressive strength has a very high (92\%) influence on the excavator bucket filling rate while the density has a high (76\%) influence and rebound hardness value has low influence (37\%). ISRM (2007) as well as Selçuk, and Yabalak (2014) reported that rebound hardness values represent the strength of rock mass within the range of $10 \mathrm{~mm}$ to $50 \mathrm{~mm}$ from the surface of the rock and that the UCS represents the value of the strength of the rock mass beyond this point. Therefore, the variation in their relationship with the excavator bucket filling rate may be as a result of the portion of the fragmented rock mass being scooped. That is, the part of the rock mass being measured by the rebound hardness number is the portion often covered by stemming and the probability of having increase particle size at this point is high. Therefore, the bucket filling rate of such area may have a reasonable relationship with the rebound hardness value and less or no relationship with uniaxial compressive strength.

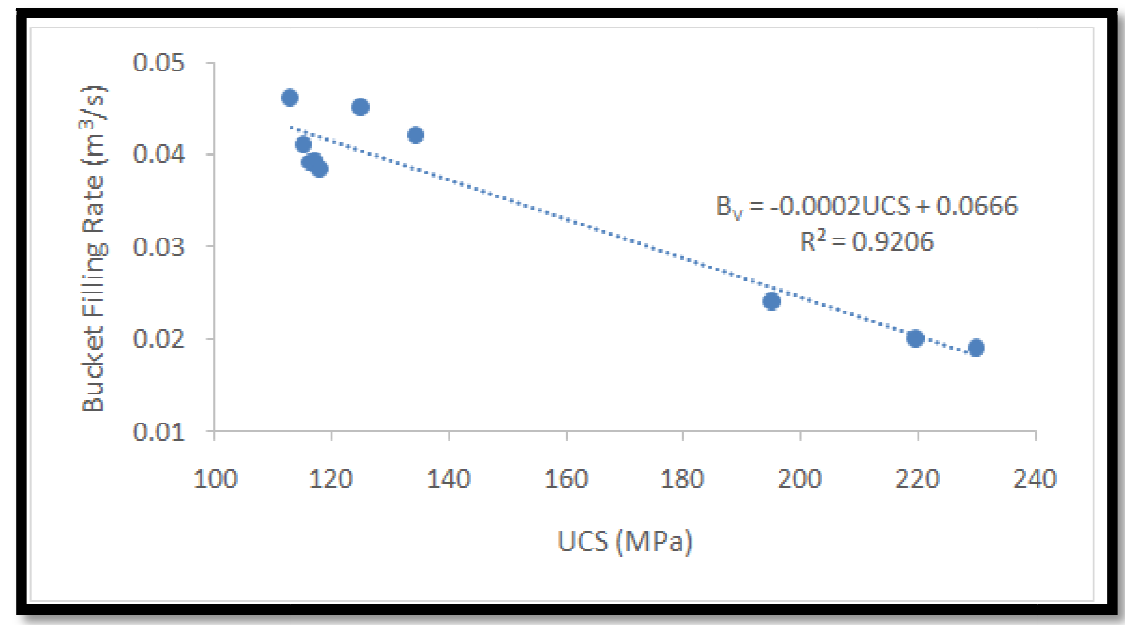

Figure 4: Relationship between Bucket Filling Rate and UCS

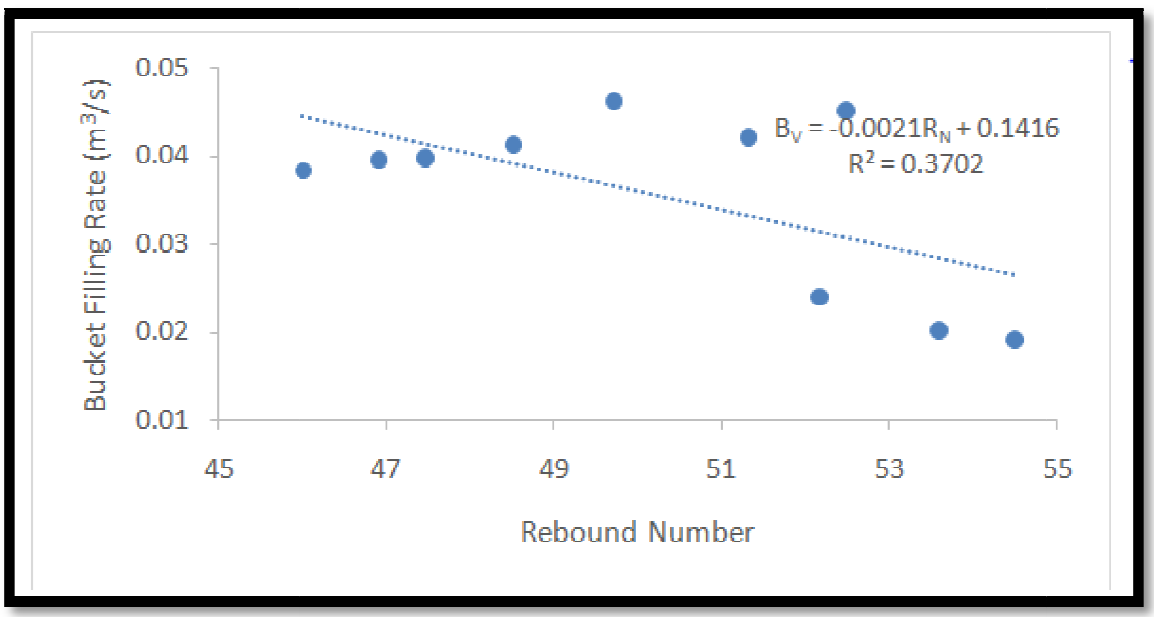

Figure 5: Bucket Filling Rate against Rebound Hardness Number

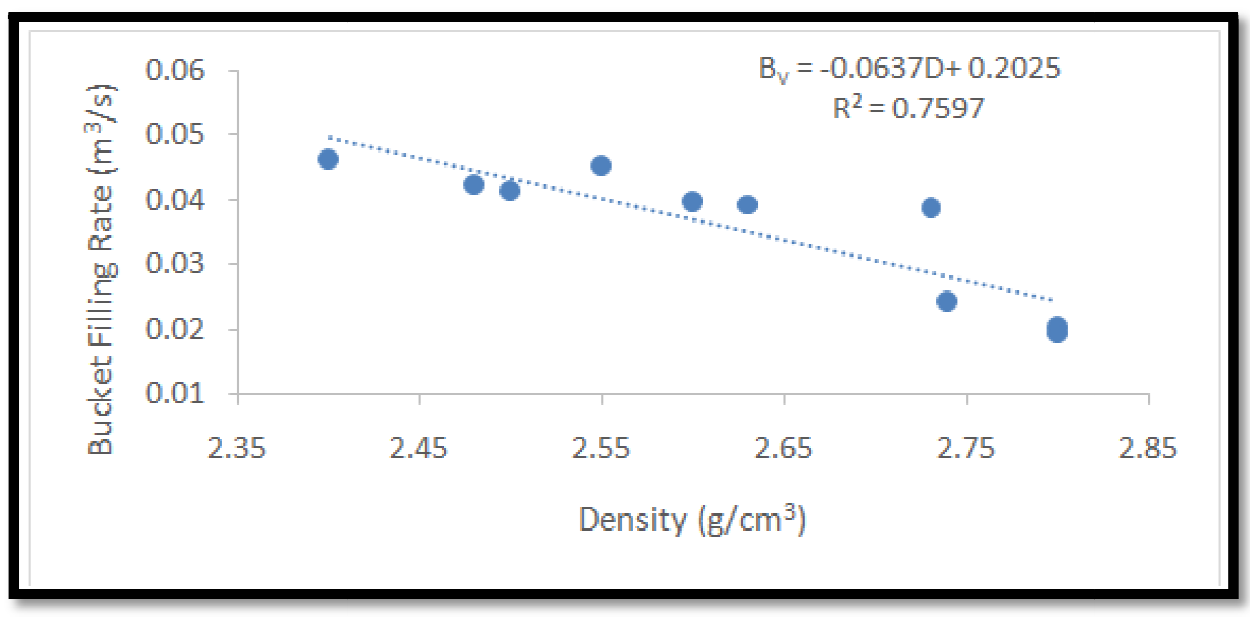

Figure 6: Relationship between Bucket Filling Rate and Density 


\section{Conclusion}

In this study, performance of excavation-hauling system of two different quarries (JCC and Dortmund) has been investigated using quarry face rock properties. Rock density test carried out on samples collected at five different excavation points of both locations revealed that the average rock density at JCC and Dortmund quarries are $2.57 \mathrm{~g} / \mathrm{cm}^{3}$ and $2.68 \mathrm{~g} / \mathrm{cm}^{3}$ respectively. The average uniaxial compressive strength of JCC is $115.90 \mathrm{MPa}$ while that of Dortmund is 185.00 MPa. Dortmund quarry has the lowest bucket filling rate of 0.0380 respectively. These values may be due to the higher density and UCS values of the quarry's rock. The coefficient of determination of the relationship between the rock properties and the bucket filling rate varies inversely with high values for uniaxial compressive strength (0.92) and density (0.76) but low value (0.37) for rebound hardness number. as the equipment performances (the higher the rock density and uniaxial compressive strength, the lower the excavator bucket filling rate, truck cycle time and vice visa). The results also show that the bucket filling rate highly influence the truck cycle time varies inversely. with Therefore, it can be concluded that strength parameters of rock play very important role in the loading-hauling systemof quarries.

\section{References}

i. Adams, K. K. and Bansah, K. J. (2016). Review of Operational Delays in Shovel - Truck System of Surface Mining

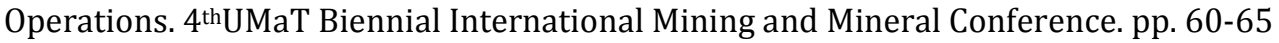

ii. Adebayo, B. and Aladejare, A. E. (2013). Effect of rock properties on excavation-loading operation in Selected quarries. Advanced Materials Research, 824, pp 86 - 90. https://doi.og/10.40.4028/scientific.net/AMR.824.86

iii. ASTM, (1994). 'Annual Book of ASTM Standards-Construction: Soil and Rocks,' ASTM Publication, West Conshohocken, p. 975.

iv. Aydan, O., Ulusay, R. and Tokashiki, N. (2014). A New Rock Mass Quality Rating System. Rock Mass Quality Rating (RMQR) and its Application to the Estimation of Geomechanical Characteristics of Rock Masses. Rock Mechanics and Rock Engineering,47, 1255-1276.

v. Heather V, Andrew G, Stefan G, Jennifer L (2011). The use of the Schmidt hammer and Equotip for Rock Hardness Assessment in Geomorphology and Heritage Science. A Comparative Analysis. Earth Surf. Proc. Land36, 320-333.

vi. Hendricks, C., Peck, J. and Scoble, M. (1991). Machine performance monitoring in Surface Mines. Mining Engineering, 44, pp. 243-250.

vii. International Society of Rock Mechanics (1981). 'Rock Characterization, Testing on Monitoring,' In: E. T. Brown, Ed., ISRM Suggested Methods, Pergamon Press, Oxford, p. 211.

viii. International Society of Rock Mechanics (2007). The Complete ISRM Suggested Methods for Rock Characterization, Testing and Monitoring: 1974-2006. International Society for Rock Mechanics, Commission on Testing Methods.

ix. Manyele, S. (2017). Analysis of Waste-Rock Transportation Process performance in an Open-Pit Mine Based on Statistical Analysis of Cycle Time Data. Journal of Engineering, 9, 649-679. https://doi.org/10.4236/eng.2017.97040

X. Mohamed, F., Hafsaoui, A., Talhi, K. and Menacer, K. (2015). Study of the Powder Factor in Surface Bench Blasting. World Multidisciplinary Earth Sciences Symposium, Procedia Earth and Planetary Science, 15, 892 - 899. https://doi.org/10.1016/j.proeps.2015.08.142

xi. Nwanya, S. C., Udofia, J. I. and Ajayi, O. O. (2017). Optimization of machine downtime in the plastic manufacturing. Cogent Engineering; 4(1), pp. 1 - 12. http://dx.doi.org/10.1080/23311916.2017.1335444

xii. Olaleye, B. M. and Adagbonyin, P. E. (2011). Simulation of loading and haulage of fragmented rock in a typical granite quarry in Ondo State, Nigeria. Journal of Emerging Trends in Engineering and Applied Sciences, 2(5), p. 884890.

xiii. Schiraldi, M. (2013). Operations Management // Using Overall Equipment Effectiveness for Manufacturing System Design, (Chapter 3), http://dx.doi.org/10.5772/56089

xiv. Selçuk, L. and Yabalak, E. (2015). Evaluation of the ratio between uniaxial compressive strength and Schmidt hammer rebound number and its effectiveness in predicting rock strength. Nondestructive Testing and Evaluation, 30(1). 1 - 12.

xv. Singh, Sp. and Narendrula, R. (2006). Factors affecting the productivity of loaders in surface mines. International Journal of Surface Mining Reclamation and Environment, 1, pp. 20-32. http://dx.doi.org/10.1080/1395260500261574

xvi. Wang, H., Lin, H. and Cao, P. (2016). Correlation of UCS Rating with Schmidt Hammer Surface Hardness for Rock Mass Classification [online]. Rock Mechanics and Rock Engineering. Available at. https://doi.org/10.1007/s00603016-1044-7 (Assessed: 18 January 2021). 